\title{
5. Experiences of Indigenous Women in the Australian Mining Industry
}

\author{
Joni Parmenter
}

\section{Introduction}

Around the world, research has shown that the introduction of large-scale mining adversely affects women in indigenous communities to a greater extent than men (Tauli-Corpuz 1997; Bhanumathi 2003; Bose 2004). A major factor that has contributed to adverse impacts experienced by women is that they have largely been excluded from negotiations concerning benefits from mineral development, including employment (Connell and Howitt 1991; Gibson and Kemp 2008). Organisations such as the World Bank and Oxfam now recognise the potential disadvantage experienced by women. They now insist on the inclusion of gender aspects in impact assessments and promote gender equality as 'smart economics' (World Bank 2006). There is a substantial body of empirical evidence to demonstrate that the social and economic empowerment of women contributes to economic growth, poverty reduction, effective governance and more sustainable development in local communities (World Bank 2001: 1).

Not all impacts of mining on women are considered adverse. There is some evidence of positive outcomes for women, such as increased access to education and travel (Robinson 2002: 43), and benefits accrued via improvements in infrastructure, such as roads and transport, which can provide access to new markets (Byford 2002). Another way women might experience benefits from mining is through employment. For a long time, mining has been considered a very masculine industry by virtue of its heavily male-dominated workforce and the physicality of mining work. Women who do gain employment in the mine are often treated with 'condescending chivalry' or treated as a novelty (Miller 2004: 49). Further, the sexist views faced by women entering the mining workforce often limit career advancement (Tallichet 2000; Gibson and Scoble 2004).

Despite a long history of working in the mining sector, sometimes performing harder or more work then their male counterparts (Amutabi and Lutta Mukebi 2001), women miners have been 'hidden from history' (Burke 2006). There is a growing body of literature on the experiences of indigenous women 
working in small-scale and artisanal mining in developing countries (LahiriDutt and Macintyre 2006), but very few sources detail their experiences in large-scale mines. Similarly, to date, there has been very limited published information on the experiences of indigenous women in the Australian mining industry. Although there have now been a few studies about female employment in the mining industry in Australia (Pattenden 1998; Kemp and Pattenden 2007) these tend to focus on the experience of non-indigenous women, who make up the majority of female employees.

Increasing the participation of women is high on the agenda of the Australian minerals industry, driven in large part by widespread skill shortages and the need to maximise the human resource pool. Concurrent with this is another, separate agenda to increase the overall participation of indigenous people in the industry (Parmenter and Kemp 2007). Because indigenous women represent the overlapping intersection of these two agendas, the specific needs of indigenous women are at risk of not being recognised or understood.

This chapter brings visibility to indigenous women in the Australian mining industry, by drawing on research conducted with indigenous female employees at Century Mine in northwest Queensland. Where relevant, reference is also made to data collected by government agencies such as the Australian Bureau of Statistics (ABS) and Australian Bureau of Resource Economics (ABARE). This chapter does not attempt to provide a comprehensive analysis of the experience of indigenous female employees in mining in Australia as there is still only limited data available. The chapter is divided in three sections. The first section presents an overview of participation in the Australian mining industry, the second section provides a case study of indigenous women working at Century Mine and the third section discusses the theoretical background and implications for incorporating indigenous women in gender mainstreaming practice. The chapter concludes by arguing that gender should not be considered in isolation to other intersecting factors such as race, and that understanding the experience of indigenous women in the mining workplace is important in contributing to long-term positive outcomes for indigenous communities.

\section{Participation in the Australian Mining Industry}

Indigenous women have worked in the mining industry in Australia since at least the 1940s (Wilson 1961, 1980, cited in Holcombe 2004). There has been a steady increase in indigenous female participation in the Australian minerals industry over time, but more sharply in recent years. One explanation for this is that Australia has experienced a resources boom, and another is the 
recent efforts of some mining companies to diversify the workforce. The data presented ahead provides some general insight into the participation of indigenous women currently working in the Australian minerals industry.

The Australian 2006 National Census identified 395 indigenous women working in mining, representing 0.4 per cent of the total mining workforce. This figure represented 16 per cent of the indigenous mining workforce, compared with a 15 per cent representation of non-indigenous women in the non-indigenous mining workforce. There has been an increase in indigenous women's representation when compared to the 2001 Census, which identified 156 indigenous females working in mining, representing 0.2 per cent of the total workforce and 11.2 per cent of the minerals industry's indigenous workforce. When viewed by commodity, the coal sector has by far the lowest overall indigenous employment rate, at only 0.3 per cent of the sector workforce (Tedesco et al. 2003). This can be explained in part by the fact that coal mining regions have a lower representation of indigenous people in the population than metalliferous mining regions. The coal sector also has the lowest representation of all women, at only 4 per cent of the sector workforce (Kemp and Pattenden 2007). In interpreting these figures it is important to note that they are likely to under-represent the true number of indigenous people due to the reluctance of some indigenous people to self-identify, and the ongoing issue of variable levels of indigenous participation in the National Census (Taylor and Bell 2004).

A recent study of indigenous employment in the Australian minerals industry, conducted by Tiplady and Barclay (2006), identified 243 indigenous women representing 2.2 per cent of the total workforce across 12 participating sites. ${ }^{1}$ Women accounted for 20 per cent of the total indigenous workforce, although there was considerable variation across sites, with female representation ranging between 8 to 33 per cent of the total indigenous workforce. The majority of male and female indigenous employees in the Indigenous Employment Study worked in semi-skilled positions (57 per cent) (see Table 5-1).

\footnotetext{
1 These sites were selected primarily on the basis that the operation and/or parent company had shown a commitment to increasing indigenous employment and would, therefore, be more likely to have higher participation rates than other sites in Australia. The largest number of case study sites were in Western Australia (seven) followed by Queensland (three) and the Northern Territory (two) (Tiplady and Barclay 2006).
} 
Gendering the Field

Table 5-1: Occupations of indigenous employees in the Indigenous Employment Study.

\begin{tabular}{lrrrr}
\hline $\begin{array}{c}\text { Occupation } \\
\text { Type }\end{array}$ & Men & Women & Total & $\begin{array}{c}\text { Indigenous workforce } \\
\text { (\%) }\end{array}$ \\
\hline Semi-skilled & 578 & 89 & 667 & 56.6 \\
Administration & 4 & 73 & 77 & 6.5 \\
Professional & 7 & 7 & 14 & 1.2 \\
Trade & 82 & 3 & 85 & 7.2 \\
Supervisor & 31 & 2 & 33 & 2.8 \\
Technical & 19 & 2 & 21 & 1.8 \\
Superintendent & 8 & 0 & 8 & 0.7 \\
Specialist & 5 & 2 & 7 & 0.6 \\
Manager & 5 & 0 & 5 & 0.4 \\
Graduate & 1 & 1 & 2 & 0.2 \\
Executive/Manager & 0 & 0 & 0 & 0 \\
Traineeship & 100 & 60 & 160 & 13.6 \\
Apprentice & 96 & 4 & 100 & 8.5 \\
\hline Total & $\mathbf{9 3 6}$ & $\mathbf{2 4 3}$ & $\mathbf{1 1 7 9}$ & \\
\hline
\end{tabular}

Source: Adapted from Tiplady and Barclay (2006).

A similar situation is seen throughout history and in other areas of the world. In India, the adivasi (indigenous people) of the collieries were concentrated in low positions (Sinha 2002), and in South Africa, professional women in mining are more likely to be white, while unskilled women in mining are more likely to be black (Ranchod 2001: 6). Excluding the indigenous women in semiskilled positions (for example, truck drivers), the categories of jobs undertaken by indigenous women tend to be aligned with those usually associated with women. ${ }^{2}$ There were significantly fewer indigenous female apprentices, tradespersons, supervisors and technical staff, and significantly more women in administration roles. A similar pattern is seen in the female mining workforce more broadly (Kemp and Pattenden 2007).

The lack of participation of indigenous women in the Australian mining industry has been attributed to several factors, some of which are not unique to indigenous women. Indigenous women are more likely to bear children at a younger age than non-indigenous women, and are often responsible for caring for larger numbers of dependents or others than non-indigenous women (ABS 2008). A young family may be a constraint in terms of starting a career; however, indigenous women often have a close extended family that may

2 'Female' roles are those work roles usually associated with women, including administration, catering, cleaning and professional support roles such as Human Resources, public relations, and community relations. Roles usually associated with men, are mining engineers, metallurgists and operational roles, such as truck driving (Kemp and Pattenden 2007). 
care for the children while they work. Dominant values in some indigenous communities regarding women's involvement in waged employment may also influence an individuals' desire to participate (O'Faircheallaigh 1998). Other cultural factors attributed to lack of participation of indigenous Australians include the availability of hunting and gathering activities in preference to jobs and whether a person's first language is English or indigenous (Hunter and Gray 1999).

The systemic societal disadvantage experienced by indigenous communities raises many complex issues. Lack of education and poor health directly affects employment prospects for indigenous people. Indigenous Australians are more likely than non-indigenous Australians to suffer from asthma, diabetes and cardiovascular disease, and are also more likely to report health risk factors such as smoking and excessive drinking (Tiplady and Barclay 2006). However, according to census data, indigenous women are less likely than indigenous men to engage in drug and alcohol abuse (a significant safety issue within the mining industry) and are also likely to be more educated than indigenous men (ABS 2006).

Two or three individual mines in Australia have been able to achieve indigenous workforce representation of up to 20 per cent of the total workforce. One of these mines is Century Mine, where the data for this chapter was collected. The next section provides an overview of Century Mine, and presents results from recent interviews with indigenous women working there.

\section{Century Mine and Indigenous Female Employees}

Mineral Metals Group's (MMG) Century Mine is a large open cut zinc mine located in the lower Gulf of Carpentaria region of North West Queensland (see Figure 5-1).

The relationship between Century Mine and adjacent communities in the Gulf of Carpentaria is generally mediated by the Gulf Communities Agreement (GCA). This is a right-to-negotiate (RTN) agreement made between Pasminco Century Mine Limited, ${ }^{3}$ (now MMG), the Queensland Government and representatives from the Waanyi, Mingginda, Gkuthaarn and Kukatj native title groups, signed under the provisions of the Commonwealth Native Title Act 1993 on 13 February, 1997. Increasing indigenous employment is a cornerstone of this agreement, however, employment is not defined in terms of gender considerations.

3 In September 1997 Pasminco purchased the Century Mine project from Rio Tinto and in March 2004 Pasminco was relaunched on the stock exchange as Zinifex. In 2008 Zinifex merged with Oxiana and relaunched on the stock exchange as OZ Minerals. In 2009, OZ minerals were sold to Minerals and Metals Group (MMG). 


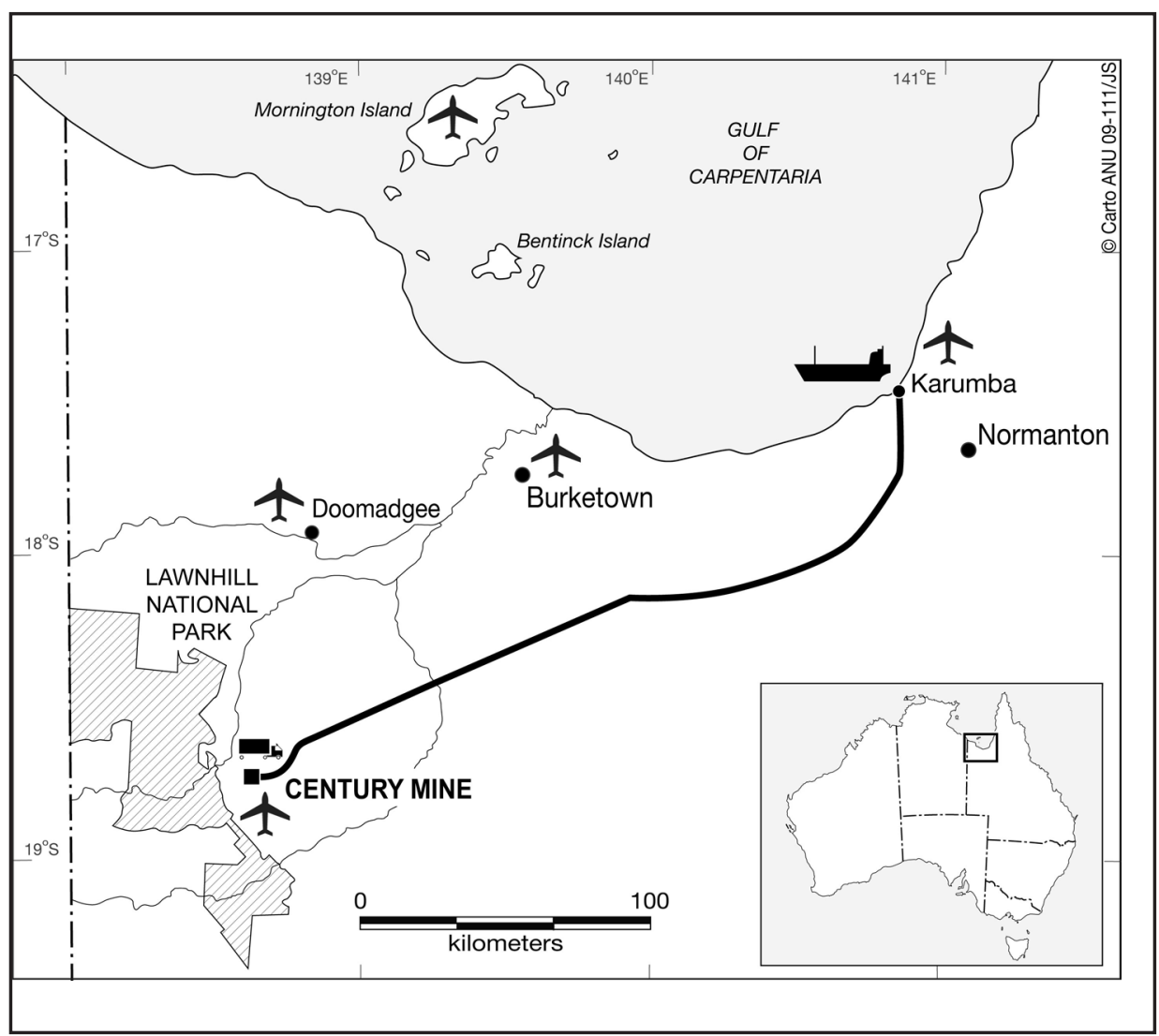

Figure 5-1: Map of Century Mine and surrounding gulf communities.

Source: Century Mine.

At the time of writing, Century Mine employed approximately 1130 employees, of whom 207 (18 per cent) are indigenous. The participation rate for both indigenous people and indigenous women is relatively higher than most other mine sites in Australia. This can be attributed partly to the fact that the mine is located in a region where there are high populations of indigenous people, and because the Gulf community's agreement includes provisions to employ indigenous people locally.

According to data supplied by Century Mine, in September 2008 there were 48 indigenous female employees working at Century Mine, representing 4.2 per cent of the total workforce and 23 per cent of the total indigenous workforce (see Table 5-2). As with indigenous men, the majority of these positions are categorised as semi-skilled; mostly as truck drivers. Jobs are aligned with those typically associated with women, with all indigenous people in administration 
positions occupied by women and all trades and apprenticeships occupied by indigenous men. There were few indigenous men and no indigenous women in supervisory or management roles.

Table 5-2: Indigenous employee positions at Century Mine: September 2008.

\begin{tabular}{lccc}
\hline \multicolumn{1}{c}{ Occupation Type } & Male & Female & Total \\
\hline Semi Skilled & 109 & 28 & 137 \\
Trade & 16 & 0 & 16 \\
Administration & 0 & 5 & 5 \\
Manager & 1 & 0 & 5 \\
Supervisor & 4 & 0 & 4 \\
Technical & 1 & 2 & 3 \\
Superintendent & 1 & 0 & 1 \\
Specialist & 0 & 0 & 0 \\
Professional & 0 & 0 & 0 \\
Apprentice & 12 & 0 & 12 \\
Traineeship & 7 & 8 & 15 \\
Unidentified & 8 & 5 & 9 \\
\hline Total & $\mathbf{1 5 9}$ & $\mathbf{4 8}$ & $\mathbf{2 0 7}$ \\
\hline
\end{tabular}

Source: Author's data.

Indigenous female employees at Century Mine live in a variety of communities and towns in northern Queensland. Some live more locally in the Gulf communities and others fly in from the larger towns of Mt Isa and Townsville. Based on interviews undertaken with 36 indigenous female employees at Century Mine, women from the Gulf communities, particularly Doomadgee and Mornington, find coming to work at Century more challenging than indigenous women from the other towns, who have more exposure to mainstream employment and lifestyles. The indigenous population represents over 90 per cent of the total population in Doomadgee and Mornington Island, both of which are disadvantaged socially and economically. For many of these women, it is not only their first experience in mainstream employment but also their first experience in a non-indigenous, male dominated environment. Indigenous women from the local Gulf communities make up 44 per cent of the total indigenous female workforce. The remaining 56 per cent live in the larger towns of Mount Isa and Townsville.

The following discussion of indigenous women's experience working at Century Mine draws on field work conducted in September 2008. Nine women were interviewed on a one-on-one basis; and three focus groups and two group interviews were undertaken. Interviews were semi-structured. Thirtysix indigenous women participated in total, representing 75 per cent of the 
indigenous women currently working at Century. Participants' ages ranged from 19 to 51 years and their periods of employment ranged from five weeks to nine years. The women interviewed worked in varied roles and areas across the site, including cleaners and kitchen hands in the village (accommodation area) and operators in the open cut pit. Some pre-vocational trainees were also interviewed. This discussion also draws on previous studies conducted by The University of Queensland's Centre for Social Responsibility in Mining (CSRM) in 2006 and 2007 involving indigenous women at Century Mine. The previous fieldwork was conducted during three visits to the mine site and surrounding communities at different times between 2005 and 2007. One study focused on community perspectives, one on the implications of closure for Gulf communities, and one on the experiences of women in mining. Multiple methods were used, including a quantitative survey, semi-structured interviews and focus groups. Some of the same indigenous female employees participated in more than one study.

\section{Indigenous Women at Century Mine: The Experience}

\section{Cultural Constraints}

Working in the mining industry may not be considered culturally appropriate for some indigenous people (Trigger 2002), whereby a responsibility exists to care for 'country'. The word 'country' was adopted by English-speaking aboriginal peoples to describe their reciprocal relationship to homelands. If you are doing the right thing ecologically, the results will be social and spiritual, and vice versa (Rose 2002: 49). Some indigenous people may therefore refrain from working in mining for this valid cultural reason. However, not surprisingly, given their employment at the mine, none of the women interviewed at Century Mine felt compromised by this factor.

For some indigenous employees, 'avoidance rules' that dictate whether individuals may communicate with each other may be problematic in the workforce environment. For example, two people who are usually not permitted to speak to each other may be required to work in the same crew, be on the same flight or supervise one another. According to indigenous women at Century, this situation does occur occasionally and management has worked around it. However, this is an informal process, so some incidents may go undetected. It is unknown if these 'avoidance rules' have a greater effect on women or men. In regard to supervision, one indigenous woman explained that age was more of an issue than gender, with older indigenous people of both genders less likely to take orders from younger people of both genders. This needs further research. 
In addition, a gender-based cultural constraint creates a very practical challenge for indigenous women at Century Mine. Among some indigenous groups in northern Australia, red ochre (hematite) is specifically the domain of men (it is important in male ceremonial contexts) and it is considered offensive and dangerous for women to touch, or be in close contact with. This clearly makes it very problematic for women to work in the open cut pit, where this material is uncovered regularly. At the request of traditional owners, Century Mine management does not allow women to work directly with ochre. Women (including non-indigenous women) are not permitted to haul the material in their trucks, and it has to be 'sheeted' ${ }^{4}$ before a woman may drive over it. Although the majority of indigenous people on site appeared to respect this cultural tradition, some non-indigenous women operators have expressed frustration. The indigenous women on the other hand, strongly support the cultural significance of this material and the associated exclusion rules. At the time of the interviews, there was a large amount of ochre in the open pit, in an area known as the 'west'. As a result, women were assigned tasks such as painting tyres, or moved over to work in an area known as the 'kingdom'. The 'kingdom' was so nicknamed due to a popular previous supervisor of ore mining, who identified the area at the time as his own; it was his 'kingdom'. When the area moves, so to does the name, which now generally refers to the area whose ore is being mined.

According to the indigenous women who work as truck drivers or water cart operators, working in the kingdom is harder work. It is a slower run, and very difficult for fatigue management. Although there is little evidence to suggest that men are abusing this cultural tradition, either to make women perform harder work or to exclude them from the pit altogether, this remains an area for further investigation. For example, at one mine site in Papua New Guinea (PNG), men have gone to extraordinary lengths to exclude women from operating the dump trucks. Objections were raised in terms of the danger of pollution: to men who had to sit in the same seat where a menstruating women had sat; to the vehicle that would be infused with dangerous emanations from female bodies and to the motor mechanics who would be exposed to the polluted sump oil that would ultimately be the repository for these emanations (Macintyre 2003: 5-6). Despite opposition from women, the mine decided not to allow women on dump trucks as it would be 'against custom' (Macintyre 2003).

There may also be implications of working at the mine that affect indigenous women in their home environments. For example, it is unknown if humbugging 5 for mining income affects women more or differently than men. At home, women from the communities of Doomadgee and Mornington Island said they

4 Sheeting refers to the laying down of material on the pit floor, usually limestone or shale.

5 'Humbugging' refers to pressuring a relative for money. 
felt added pressure to share their money (humbug) since working at the mine. One woman said: 'Our money is not our money, we gotta share it ... aboriginal way. Pressure to share with kin or 'demand sharing' is noted in the literature for both genders (Petersen 1993; Trigger 2005) and is important in the constitution of social relations in egalitarian societies. Currently little is known about how income from mining employment is distributed by indigenous workers and how many people benefit. Further, as O'Faircheallaigh (1998) pointed out over a decade ago, there is a need to determine whether waged employment will sharpen or reduce inequality between indigenous men and women.

\section{Extra Burdens}

Some of the experiences of the indigenous women interviewed are not unique to indigenous women, such as the pressures of family responsibilities and issues associated with working in such a male-dominated environment (Kemp and Pattenden 2007). However, these issues can be compounded for indigenous women, who often have additional cultural or extended family responsibilities, and are more likely to come from socio-economically disadvantaged communities than non-indigenous women. Further, indigenous women may endure the extra burden of experiencing racism as well as sexism. This may explain why the great majority of indigenous women at Century Mine perceived themselves as occupying the bottom position of the mine site 'hierarchy', where nonindigenous men are at the top, followed by non-indigenous women, indigenous men and then them. The women are both indigenous and female- a double minority resulting in the bottom position.

Many indigenous women at Century spoke of the extra burden of having family responsibilities and the need to 'prove yourself' at a mine site. One woman said:

The most annoying thing is that women work hard and they are still the mothers, they still got to do all the work at home and come up here and have to do more work than men because they have to prove themselves, its even harder for an indigenous woman, feel like you're being monitored more.

The indigenous women who worked in the open cut pit felt more pressure from their male colleagues compared to women in other areas on site, where women were represented in greater numbers. One woman from the pit said:

Can't be weak, can't take everything to heart, have to be able to relate to men ... they shit-stir you, try to make you break, try to make you leave ... that's their idea of having a good time. 
If women showed any form of weakness they were reminded of their 'femaleness'. For example, a group of women agreed that whenever there was a circumstance when they had to leave their shift due to illness, responses from men included: 'You're going home early because you are a woman, if you were a man you'd stay', whereas nobody said anything to male workers in the same situation.

Many of the women thought it was harder for women to get promoted than men, and even harder for indigenous women. One woman said: 'Mining has always been a men's thing. We are the cleaners, we never get anywhere else. Men can always get in before a woman because it's mining'. A few women who had some experience in a temporary supervisory role, said that the men they supervised were unwilling to take orders. One woman said: 'Men don't like taking orders from a woman, if a bloke ${ }^{6}$ tells them they go out and do it straight away, but if we do they don' $t^{\prime}$. Another woman told a story of how she managed this 'push back' from men:

I wrote instructions for the day on the board, rather than tell them directly, if I did have to speak to them, I'd start with: 'Would you mind doing me a favour?'

In a previous CSRM study that involved indigenous women at Century Mine (Kemp and Pattenden 2007), one woman commented on how she thought nonindigenous supervisors perceived indigenous female employees:

They don't take you seriously ... they're not going to listen to a woman, think a woman can't know any better than they do, especially a black woman.

Indigenous women in the current study confirmed this position. One woman said:

White women get looked after-do they think we are not intelligent enough to move up to these positions? I mean we're not back in the Stone Age, there are some smart aboriginals out there.

Almost all interviewees said they felt they were overlooked for promotions, or less favoured by supervisors (who are almost entirely non-indigenous males) because they were both indigenous and female, and therefore 'especially dumb'. One woman noted that in reality, indigenous women were more likely to be more highly educated than indigenous men in their community. This is confirmed by ABS statistics (ABS 2006).

All indigenous women interviewed felt that non-indigenous women were favoured for career advancement and generally more supported by non-

6 'Bloke' is a colloquial expression for 'man'. 
indigenous male supervisors. One woman commented that unlike new indigenous female employees, new non-indigenous female employees in the open cut pit were made to feel welcome. Their names were known within a few days, with supervisors congratulating and flirting with them on the mines communication channel: 'It's like ... "welcome to our group," sort of thing.' The indigenous women also thought that non-indigenous women were more aggressive, more likely to complain and, therefore, more likely to get promoted or secure training opportunities than indigenous women. They said indigenous women were less likely to complain and 'just do what they're told' and were therefore more likely to be taken advantage of and allocated the unpleasant jobs.

The majority of women at Century self-identify with being a member of an oppressed racial group, before being female. This is not to say that indigenous men are innocent of the same chauvinist attitudes that non-indigenous women have accused non-indigenous men of holding (Huggins 1987). A few of the women interviewed said that working at the mine has enabled them to have more independence from their husbands, who they perceived to be too controlling. One woman said:

Before I worked, my husband expected me to stay home with the kids all day while he was at work, and then all night as well while he went to the pub ... now we share.

Indirectly, indigenous men were criticised by many of the women for what was termed 'jealousy'. Many women said that this jealousy was the main barrier preventing indigenous women from working at the mine. People in indigenous communities did not want their partners to come and work for the mine, assuming there are too many opportunities for infidelity. Although this jealousy is apparently felt by both genders, clearly it would affect more women given that the mine site is so male dominated. One woman said that this jealousy is such a major factor, that women in her community had previously been forced to choose between their partner and their job. This jealousy also prevented women from attending the wet mess (bar) on site, in order to avoid married men and starting rumours back in the community. Some also thought it was uncomfortable visiting the bar because of the perceptions held by nonindigenous men: '[T]hey just stare at you, assuming you are on the piss ... you feel preyed upon'.

The majority of indigenous women interviewed felt strongly about being 'looked down on' by both non-indigenous men and women, but were much less critical of indigenous men, seemingly preferring to 'stick together' as indigenous people, against what they saw as the more dominant oppressor-white men and women. As Huggins (1987) stated 20 years ago, it is easier for an indigenous woman to consider herself first a human being, second an indigenous person and 
third a member of the female sex, viewing disadvantages of race and class before those of sex. This relates to the indigenous feminist literature that recognises the intersection of gender, race and colonialism (Green 2007), discussed ahead.

\section{Gender Mainstreaming and Intersectionality}

There is now general agreement that the mining industry is highly gendered and the negative impacts of mining are greater for women than for men (TauliCorpuz 1997; Bhanumathi 2003; Bose 2004). Less is known about the relationship between other intersecting factors such as race and class between men and women and between women as a group. The relationship between gender inequality and other complex inequalities is an important and unresolved debate in both

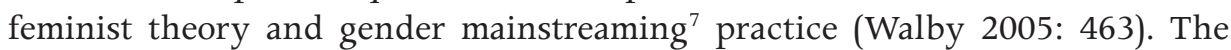
Century case indicates that some female aboriginal mine workers view issues of race as more important than those of sex. This is further supported by African American feminists of the 1970s (Spelman 1988) and the emerging literature on indigenous feminism (Green 2007).

Feminism is a complex subject that has not only redefined itself throughout history but continues to be debated. The commonality between all the different forms of feminism - and there are several - is that they have all arisen out of conditions of patriarchy. Therefore, for women who do not perceive their society to be patriarchal, or do not believe they experience oppression from a patriarchal society, feminism is considered irrelevant (Green 2007). This is the case for some indigenous women, who argue that male domination is not universal (Turpel 1993; Monture-Angus 1995). Further, as Monture-Angus (1995) attests, accepting the western idea of 'equality' would mean accepting a lower position than what has historically been accorded to women in her culture. Some Australian indigenous women have expressed similar views towards the women's movement (Huggins 1994; Moreton-Robinson 2000). In 1994, Huggins suggested there was no support for the women's movement from within indigenous circles. Ten years later, Fredericks (2004) wrote: 'We stand and watch non-indigenous women argue for something which we had and which they assisted in disempowering us of'. When western women were addressing their sexual oppression by men via the feminist movement, indigenous women

7 Gender mainstreaming is the process of assessing the implications for women and men of any planned action, including legislation, policies and programs, in all areas and at all levels. It is a strategy for making women's as well as men's concerns and experiences an integral dimension of the design, implementation, monitoring and evaluation of policies and programs in all political, economic and societal spheres so that women and men benefit equally and inequality is not perpetuated. The ultimate goal is gender equality (UN ECOSOC 1997: 2). 
(and men), were addressing many forms of oppression by the dominant western society. Therefore, indigenous women are coming from a very different position than western women.

Green (2007) argues that whether or not indigenous women have experienced patriarchal oppression within their own cultures and communities, they are subjected to the patriarchal and colonial oppression within the dominant western society. There is now a small body of literature emerging on indigenous feminism, as evidenced by Green's 2008 work, titled Making Space for Indigenous Feminism. Some indigenous scholars who once rejected feminism are now acknowledging its importance and identifying themselves as indigenous feminists (Bear 2007; St Denis 2007). Indigenous feminists raise issues of colonialism, racism and sexism, and the unpleasant synergy between these violations of human and political rights (Green 2007: 20). In the case of mining, this synergy is likely to be further exacerbated for indigenous female employees given that the Australian mining industry is western, masculine, and heavily dominated by non-indigenous male workers.

If race and class have historically come before gender for indigenous women as barriers to their advancement, the question remains as to how and if gender mainstreaming is appropriate for indigenous women, and if so, how it can be implemented in the mining industry. Gender mainstreaming has been widely adopted by international aid agencies for some time as a key strategy for achieving gender equality. However, for the mining industry, it is a relatively new concept. With the advent of the United Nations (UN) Millennium Development Goals (MDG), the mining industry has taken note. The MDG assigns collective responsibility for halving world poverty by 2015, with an explicit commitment to gender equality as an end in itself. In 2009, the mining company Rio Tinto produced a resource guide for integrating gender considerations into community work at their operations. This is one of the first publicly-articulated, community-oriented gender frameworks developed by a multinational mining company. However, indigenous women and the intersection between race and gender is not a focus.

Gibson and Kemp (2008) use the term 'double blind' to describe corporate engagement that tends to overlook the nexus between gender and indigeneity. There is little evidence that the industry's agenda to increase the employment of indigenous people includes a gender dimension, and little evidence that the agenda to increase the participation of women includes an indigenous component. At a site level, there is some evidence of consideration for indigenous cultural issues, such as allowing leave for funerals and compulsory cultural awareness training for all employees, but these are not gender specific. In this sense, the 
Australian mining industry has, not unlike western feminist theory and gender mainstreaming practice, failed to consider the intersection between race and gender.

Current debate exists about whether it is preferable to adopt the concept of diversity mainstreaming. Both gender mainstreaming and diversity mainstreaming are contested concepts. Some have argued that the concept of gender is invariably tied to the male-female binary and therefore limited in its ability to reflect differences among women (Hankivsky 2005, Squires 2005, Walby 2005). Take for instance indigenous women's ready acceptance of gender exclusion rules that apply with the management of red ochre in the Century pit. Unlike non-indigenous women, there is acceptance because the exclusion is culturally based and shows identification with their aboriginality taking precedence over any concerns about gender inequality. Others are concerned that by putting all inequalities together under the one umbrella of 'diversity', risks overlooking political intersectionality and may cause dilution of the feminist agenda (Mackay and Bilton 2003; Verloo 2006).

In a recent gender analysis study that produced guidelines for the Western and South Australian state public sectors, indigenous female representatives expressed strong reservations about the usefulness of the concept 'gender' (Bacchi and Eveline 2009). Gender was understood to privilege male/female relations and was considered problematic for their social analysis of racialisation (ibid.). Further, using the very word 'mainstreaming' proved difficult due to its association with political moves to disband the democratically elected representative body of Aboriginal and Torres Strait Islander Commission (ATSIC) (Pratt and Bennett 2004-2005). The issue was resolved by introducing 'race and cultural analysis' as informing gender analysis. Race and cultural analysis requires the whole discussion of equality and equity to be rethought through the perspective of aboriginal people (Bacchi and Eveline 2009). Although Bacchi and Eveline (ibid.) do not suggest introducing this analysis as a model for developments elsewhere, the need to respond to on-the-ground political developments has merit. Gender mainstreaming for the mining industry may need to consider a non-generic approach to implementation that also reflects the current level of theoretical development concerning the question of gender and its intersecting relations.

\section{Conclusion}

This chapter has discussed key findings from recent research that substantially involved indigenous women working at Century Mine. The research has highlighted how the challenges faced by women working in the Australian 
mining industry can be compounded for indigenous women due to additional familial and cultural responsibilities. For many indigenous women who live in remote communities, this is their first experience in mainstream employment, in an environment that is heavily dominated by non-indigenous and mostly male workers. Indigenous women are both indigenous and female, a double minority in a very unfamiliar environment, thereby conflating the experiences of both sexism and racism.

On a global level, it is important that the resources industry does not consider gender alone, but includes other intersecting identities and factors such as race, class and the local socio-political and cultural context of the women affected. The Australian mining industry has so far failed to consider the intersection between race and gender. The industry's agenda to increase the participation of women in the workforce does not include an indigenous component, and the agenda to increase indigenous participation in the workforce does not include a gender component.

This chapter is a first step in bringing visibility to the experience of indigenous female employees in the Australian mining industry. Although this research provides insight into some indigenous women's experiences in mining employment, further dedicated research focusing on indigenous women in mining is warranted. If mining companies are to attract and retain more indigenous women, as well as contribute to the long term sustainability of indigenous communities, it is crucial that they understand and respond to the impacts of employment more fully.

\section{References}

Amutabi, M. and M. Lutta Mukebi, 2001. 'Gender and Mining in Kenya: The Case of Mukibirs Mines in Vihiga District.' Jenda: A Journal of Culture and African Womens Studies 1(2): 1-23.

ABS (Australian Bureau of Statistics), 2006. 'Census of Population and Housing.' Canberra: Australian Bureau of Statistics.

\section{Statistics.}

Bacchi, C. and J. Eveline, 2009. 'Gender Mainstreaming or Diversity Mainstreaming? The Politics of "Doing".' NORA: Nordic Journal of Feminist and Gender Research 17(1): 2-17.

Bear, S., 2007. 'Culturing Politics and Politicising Culture.' In J. Green (ed), op.cit. 
Bhanumathi, K., 2003. 'Women and Mining in India.' Paper presented at conference on 'Women in Mining', Melbourne, 3 August.

Bose, S., 2004. 'Positioning Women within the Environmental Justice Framework: A Case for the Mining Sector.' Gender, Technology and Development 8(3): 407-12.

Burke, G., 2006. 'Women Miners: Here, Now and Then.' In K. Lahiri-Dutt and M. Macintyre (eds), op.cit.

Byford, J., 2002. 'One Day Rich: Community Perceptions of the Impact of the Placer Dome Gold Mine, Misima Island, Papua New Guinea.' In I. Macdonald and C. Rowland (eds), op.cit.

Connell, J. and R. Howitt (eds), 1991. Mining and Indigenous Peoples in Australasia. Sydney: Sydney University Press.

Fredericks, B., 2004. 'A Reconstituted Social Environment: Feminism and the Plight of Aboriginal Women in Australia.' Newtopia Magazine, IdeologicalIssue 3(18).

Gibson, G. and D. Kemp, 2008. 'Corporate Engagement with Indigenous Women in the Minerals Industry: Making Space for Theory.' In C. O'Faircheallaigh and S. Ali (eds), Earth Matters: Indigenous Peoples, the Extractive Industries and Corporate Social Responsibility. Sheffield: Greenleaf Publishing.

Gibson, G. and M. Scoble, 2004. 'Regendering Mining: A Survey of Women's Career Experiences in Mining' CIM Bulletin, 97(1082): 55-61.

Green, J., 2007. 'Taking Account of Aboriginal Feminism.' In J. Green (ed.), op.cit.

Green, J., (ed.), 2007. Making Space for Indigenous Feminism. Canada: Fernwood Publishing

Hankivsky, O., 2005. 'Gender vs Diversity Mainstreaming: A Preliminary Examination of the Role and Transformative Potential of Feminist Theory.' Canadian Journal of Political Science 38(4): 977-1001.

Holcombe, S., 2004. 'Early Indigenous Engagement with Mining in the Pilbara: Lessons from a Historical Perspective.' Canberra: Centre for Aboriginal Economic Policy Research (Working Paper 24). Viewed 7 March 2006 at http://www.anu.edu.au/caepr/Publications/WP/CAEPRWP24.pdf

Hunter, B. and M. Gray, 1999. 'Further Investigations into Indigenous Labour Supply: What Discourages Discouraged Workers?' Canberra: Centre for Aboriginal Economic Policy Research (Working Paper 2). 
Huggins, J., 1987. 'Black Women and Women's Liberation.' Hecate: An Interdisciplinary Journal of Women's Liberation 13(1): 77-82.

, 1994. 'A Contemporary View of Aboriginal Women's Relationship to the White Women's Movement.' In N. Grieve and A. Burns (eds), Australian Women and Contemporary Feminist Thought. South Melbourne: Oxford University Press.

Kemp, D. and C. Pattenden, 2007. 'Retention of Women in the Minerals Industry.' In Centre for Social Responsibility in Mining Team (eds), Unearthing New Resources: Attracting and Retaining Women in the Australian Minerals Industry. Canberra: Australian Government Office for Women, Minerals Council of Australia, Women in Social and Economic Research and Centre for Social Responsibility in Mining. Viewed 6 September 2010 at http://www. csrm.uq.edu.au/docs/women-in-mining.pdf

Lahiri-Dutt, K. and M. Macintyre (eds), 2006. Women Miners in Developing Countries: Pit Women and Others. Aldershot: Ashgate.

Macdonald, I. and C. Rowland (eds), 2002. Tunnel Vision: Women, Mining and Communities. Melbourne: Oxfam Community Aid Abroad.

Macintyre, M., 2003. 'The Changing Value of Women's Work on Lihir.' Paper presented at conference on 'Women in Mining: Voices for Change.' Madang, 3-6 August.

MacKay, F. and K. Bilton, 2003. 'Learning from Experience: Lessons in Mainstreaming Equal Opportunities.' Edinburgh: University of Edinburgh, Governance of Scotland Forum. Viewed 6 September 2010 at http://www. scotland.gov.uk/Publications/2003/05/17032/21487

Miller, G., 2004. 'Frontier Masculinity in the Oil Industry: The Experience of Female Engineers.' Gender, Work and Organization 11(1): 47-73.

Monture-Angus, P., 1995. Thunder in My Soul: A Mohawk Woman Speaks. Halifax: Fernwood Publishing.

Moreton-Robinson, A., 2000. Talkin' Up to the White Women: Indigenous Women and Feminism. St. Lucia: University of Queensland Press.

O'Faircheallaigh, C., 1998. 'Resource Development and Inequality in Indigenous Societies.' World Development 26(3): 381-94.

Parmenter, J. and D. Kemp, 2007. 'Indigenous Women in Mining Employment in Australia.' Paper presented at conference on 'Sustainable Development.' Cairns, 29 October-2 November. 
Pattenden, C., 1998. 'Women in Mining: A Report to the "Women in Mining" Taskforce of the AusIMM.' Melbourne: AusIMM.

Peterson, N., 1993. 'Demand Sharing: Reciprocity and the Pressure for Generosity among Foragers.' American Anthropologist 95(4): 860-74.

Pratt, A. and S. Bennett, 2004-2005. 'The End of ATSIC and the Future Administration of Indigenous Affairs.' Canberra: Parliamentary Library (Current Issues Brief 4, 2004-2005). Viewed 17 July 2010 at http://www. aph.gov.au/library/pubs/CIB/2004-05/05cib04.htm

Ranchod, S., 2001. 'Gender and Mining: Workplace.' Johannesburg: African Institute of Corporate Citizenship. Viewed 10 June 2008 at http://www. naturalresources.org/minerals/cd/mmsd_saf.htm

Robinson, K., 2002. 'Labour, Love and Loss: Mining and the Displacement of Women's Labour.' In I. Macdonald and C. Rowland (eds), op. cit.

Rose, D.B., 2002. Country of the Heart: An Indigenous Homeland. Canberra: Aboriginal Studies Press.

St Denis, V., 2007. 'Feminism is for Everybody: Aboriginal Women, Feminism and Diversity.' In J. Green (ed.), op. cit.

Sinha, S., 2002. 'Colonialism and Capitalism: Unearthing the History of Adivasi Women Miners of Chotangapur.' In K. Lahiri-Dutt and M. Macintyre (eds), op. cit.

Squires, J., 2005. 'Is Mainstreaming Transformative? Theorising Mainstreaming in the Context of Diversity and Deliberation Social Politics.' International Studies in Gender, State and Society 12(3): 366-88.

Spelman, E., 1998. Inessential Woman: Problems of Exclusion in Feminist Thought. Boston: Beacon Press.

Tallichet, S.E., 2000. 'Barriers to Women's Advancement in Underground Coal Mining.' Rural Sociology 65(2): 234-53.

Tauli-Corpuz, V., 1997. 'The Globalization of Mining and its Impact and Challenges for Women', Paper presented at conference on 'Women and Mining', Baguio City, 20-8 January.

Taylor J. and M. Bell, (eds), 2004. Population Mobility and Indigenous Peoples in Australasia and North America. London: Routledge. 
Tedesco, L., M. Fainstein and L. Hogan, 2003. 'Indigenous People in Mining.' Canberra: Australian Bureau of Agricultural and Resource Economics (eReport 03.19). Viewed 12 September 2007 at http://abareonlineshop.com/ product.asp? prodid $=12599$

Tiplady, T. and M. Barclay, 2006. 'Indigenous Employment in the Minerals Industry.' Brisbane: Centre for Social Responsibility in Mining. Viewed 17 July 2010 at http://www.csrm.uq.edu.au/docs/CSRM\%20Report_ FINAL \%20TO\%20PRINT_singles.pdf

Trigger, D., 2002. 'Large Scale Mining in Aboriginal Australia: Cultural Dispositions and Economic Aspirations in Indigenous Communities.' In Proceedings of Council of Mining and Metallurgical Institutions Congress 2002: International Codes, Technology and Sustainability for the Minerals Industry. Carlton: Australasian Institute of Mining and Metallurgy.

, 2005. 'Mining Projects in Remote Aboriginal Australia: Sites for the Articulation and Testing of Economic and Cultural Futures.' In D. AustinBroos and G. Macdonald (eds), Culture, Economy and Governance in Aboriginal Australia. Sydney: Sydney University Press.

Turpel, M.E., 1993. 'Patriarchy and Paternalism: The Legacy of the Canadian State for the First Nations Women.' Canadian Journal of Women and Law 6(1): 174-92.

UN ECOSOC(United Nations Economic and Social Council), 1997. 'Mainstreaming the Gender Perspective into all Policies and Programs in the United Nations System.' Geneva: United Nations.

Verloo, M., 2006. 'Multiple Inequalities, Intersectionality and the European Union.' The European Journal of Women's Studies 13(3): 211-28.

Walby, S., 2005. 'Introduction: Comparative Gender Mainstreaming in a Global Era.' International Feminist Journal of Politics 7(4): 453-70.

World Bank, 2001. Engendering Development-Through Gender Equality in Rights, Resources and Voice. New York: Oxford University Press.

— 2006 'Gender Equity as Smart Economics: A World Bank Group Gender Action Plan', Washington: World Bank. Viewed 17 July 2010 at http:// siteresources.worldbank.org/INTGENDER/Resources/GAPNov2.pdf 